\title{
Upaya Meningkatkan Indeks Pembangunan Manusia dengan Pemenuhan Kebutuhan Pokok Mahasiswa UNESA Terdampak Covid-19
}

\author{
Lucky Rachmawati*, Khusnul Fikriyah, Rachma Indrarini, \\ Ladi Wajuba Perdini, Nurul Hanifa \\ Jurusan Ilmu Ekonomi, Fakultas Ekonomi, Universitas Negeri Surabaya \\ *Corresponding Author: luckyrachmawati@unesa.ac.id
}

\begin{abstract}
The aim of implementing this community service is expected to support government programs in an effort to increase the Human Development Index by Fulfilling the Basic Needs of UNESA Students Affected by Covid-19. The method of implementing activities starts from tracking information affected by Covid-19, identifying partner problems, determining solutions to be offered, implementing PKM activities, monitoring and evaluation, and the final stage is compiling reports. Participants in PKM activities are students receiving basic needs packages of 50 students. The result of this activity is the Fulfillment of the Basic Needs of UNESA Students Affected by Covid-19, of course this activity can support government programs in an effort to increase the Human Development Index.
\end{abstract}

Abstrak: Tujuan dari pelaksanaan pengabdian kepada masyarakat ini adalah untuk menunjang program pemerintah dalam upaya meningkatkan Indeks Pembangunan Manusia dengan Pemenuhan Kebutuhan Pokok Mahasiswa UNESA Terdampak Covid-19. Metode pelaksanaan kegiatan dimulai dari pelacakan informasi terdampak Covid-19, identifikasi masalah mitra, menentukan solusi yang akan ditawarkan, pelaksanaan kegiatan PKM (pengabdian kepada masyarakat), monitoring dan evaluasi, serta tahap akhir adalah menyusun laporan. Peserta kegiatan PKM (Pengabdian Kepada Masyarakat) adalah mahasiswa penerima paket kebutuhan pokok sejumlah 50 mahasiswa. Hasil dari kegiatan ini adalah Pemenuhan Kebutuhan Pokok Mahasiswa UNESA Terdampak Covid-19 dan sebagai upaya mendukung pemerintah untuk meningkatkan indeks pembangunan manusia
Article History:

Received: $12-11-2020$

Reviewed: 23-01-2021

Accepted: 03-04-2021

Published: 05-05-2021

Key Words:

Human

Development Index,

Basic Needs, Covid19.

\section{Sejarah Artikel:}

Diterima: 12-11-2020

Direview: 23-01-2021

Disetujui: 03-04-2021

Diterbitkan: 05-05-2021

Kata Kunci:

Indeks Pembangunan

Manusia, Kebutuhan

Pokok, Covid-19.

How to Cite: Rachmawati, L., Fikriyah, K., Indrarini, R., Perdini, L., \& Hanifa, N. (2021). Upaya Meningkatkan Indeks Pembangunan Manusia dengan Pemenuhan Kebutuhan Pokok Mahasiswa UNESA Terdampak Covid-19. Jurnal Pengabdian UNDIKMA, 2(1), 18-23. doi:https://doi.org/10.33394/jpu.v2i1.3128

doi:https://doi.org/10.33394/jpu.v2i1.3128

This is an open-access article under the CC-BY-SA License.

\section{Pendahuluan}

Menurut Organisasi Kesehatan Dunia (WHO) "Covid-19 atau Corona Virus Disease adalah penyakit menular yang disebabkan oleh jenis corona virus yang baru ditemukan ini merupakan virus baru dan penyakit yang sebelumnya tidak dikenal sebelum terjadi wabah di Wuhan, Tiongkok, bulan Desember 2019”. Berdasarkan data yang dipublikasikan oleh WHO pada 26 Mei 2020, sebanyak 5.406.282 data kasus positif dan sebanyak 216 kota atau area yang terdapat kasus Covid-19, salah satunya adalah Indonesia. Pada tanggal11 Maret 2020 Organisasi Kesehatan Dunia (WHO) menetapkan "Corona Virus Disease 2019" menjadi Pandemi Internasional. Artinya negara-negara di seluruh dunia harus merespon, mencegah serta menangani pandemic virus Corona, termasuk Negara Indonesia”.

Surabaya menjadi kota pertama yang menunjukkan angka tertinggi kasus Covid-19 di Provinsi Jawa Timur dan terus menunjukkan angka peningkatan setiap harinya. Dilansir dari 
infocovid.jatimprov.go.id jumlah penderita Covid-19 di Surabaya sebanyak 2118 orang dengan penambahan kasus per 26 Mei 2020 sebanyak 23 orang, angka tersebut menjadi jumlah penyumbang pasien Covid-19 tertinggi di Jawa Timur.

\begin{tabular}{|c|c|c|c|c|}
\hline \multicolumn{5}{|c|}{ Kasus Per Wilayah } \\
\hline Terugestal & Wllayah & Konfirmasl & Konfirmaat Sernbuh & Konfirmasi Meninesal \\
\hline $26 / 5 / 2020$ & Surabaya Barat & 241 & 32 & 15 \\
\hline $26 / 5 / 2020$ & Surabaya Pusat & 300 & 19 & 38 \\
\hline $26 / 5 / 2020$ & Surabaya Selatan & 440 & 53 & 36 \\
\hline $28 / 5 / 2020$ & Surabaya Timur & 737 & 61 & 50 \\
\hline $26 / 9 / 2020$ & Surabaya Utara & 400 & 28 & 52 \\
\hline
\end{tabular}

Sumber: https://lawancovid-19.surabaya.go.id,(2020).

\section{Gambar 1. Jumlah Orang yang Terinfeksi Corona di Surabaya}

Menurut data pada Gambar 1 diatas, jumlah orang yang terkonfirmasi positif belum mengalami penurunan yang signifikan bahkan cenderung meningkat. Peningkatan ini disebabkan oleh masyarakat yang tidak menerapkan protokol kesehatan dan melanggar aturan pemerintah, diantara pelanggaran yang dilakukan masyarakat yakni tidak mau melakukan Sosial Distancing atau tidak mau melakukan Pembatasan Sosial Berskala Besar.

Adanya pandemic Covid-19 memiliki dampak baik langsung maupun tidak langsung. Secara tidak langsung, pandemi Covid-19 memiliki dampak pemerosotan perekonomian (Yamali; 2020). Covid-19 juga memiliki dampak pada perekonomian di Surabaya dan khususnya pada Mahasiswa Unesa terkait pendapatan kepala keluarga yang mendukung perekonomian keluarga mahasiswa tersebut. Universitas Negeri Surabaya sebagai salah satu Perguruan Tinggi perlu mengambil peran dalam rangka membantu pemerintah menanggulangi Covid-19. Salah satu bentuk bantuan UNESA adalah melalui penyelenggaraan Pengabdian Kepada Masyarakat kebijakan Fakultas Ekonomi yang berfokus pada penanganan Covid-19. Dalam kondisi darurat seperti ini masyarakat sangat membutuhkan bantuan dari beberapa pihak. Apalagi sampai saat ini belum ada kepastian kapan pandemi ini akan berakhir.

Tim Pengabdian Kepada Masyarakat (PKM) mengusulkan untuk melakukan penyaluran dana PKM dalam bentuk penyaluran bantuan kebutuhan pokok, dilakukan dalam rangka memenuhi kebutuhan Mahasiswa UNESA yang terdampak Covid-19. Pendistribusian paket kebutuhan pokok mendukung upaya pemerintah dalam upaya meningkatkan Indeks Pembangunan Manusia yang merupakan ukuran kesejahteraan masyarakat. Salah satu indikator dari Indeks Pembangunan Manusia adalah tingginya standar hidup masyarakat, yang dapat didukung dengan penyaluran bahan kebutuhan pokok. Tingginya standar hidup masyarakat menggambarkan kemudahan masyarakat dalam menikmati hasil pembangunan apalagi pada masa sulit ekonomi akibat pandemi Covid-19. Selain itu dengan adanya bantuan sembako diharapkan dapat mengurangi biaya kebutuhan mahasiswa yang membutuhkan (Aji: 2020).

Mahasiswa sebagai generasi penerus, juga perlu mendapatkan perhatian dalam peningkatan standar hidup mereka. Menempuh studi dalam kondisi pandemi corona, tidaklah mudah. Mereka bergantung pada orang tua mereka yang kondisinya juga belum tentu sebaik sebelum masa pandemi. Kegiatan pengabdian yang sejalan dengan kegiatan Pengabdian ini, sebelumnya juga telah dilaksanakan juga oleh beberapa Tim Pengabdian Kepada Masyarakat 
pendahulu dan telah mempublikasikan hasil kegiatan pengabdian mereka. Riyanta dkk. (2020) melaksanakan kegiatan pengabdian kepada masyarakat dengan memberikan paket bantuan kepada masyarakat upah harian lepas dan mendapat respon yang sangat baik dari masyarakat. Berbeda dari kegiatan pengabdian ini, Risfianty dan Indrawati (2020) menunjang program pemerintah dalam upaya meningkatkan Indeks Pembangunan Manusia dari indikator yang berbeda yakni dari segi kesehatan, sebagai salah satu indikator Indeks Pembangunan Manusia. Mereka memberikan edukasi terkait mencuci tangan dengan sabun dan air mengalir serta menyalurkan fasilitas cuci tangan secara langsung kepada masjid dan mushalla di dusun Montong Are Tengah.

Adapun tujuan dari pelaksanaan PKM ini diharapkan dapat menunjang program pemerintah dalam upaya meningkatkan Indeks Pembangunan Manusia dengan Pemenuhan Kebutuhan Pokok Mahasiswa UNESA Terdampak Covid-19.

\section{Metode Pengabdian}

Metode pelaksanaan kegiatan pengabdian ini dapat dilihat pada Gambar 2 dibawah. Dimulai dari pelacakan informasi terdampak Covid-19, sehingga dapat diidentifikasi masalah mitra. Kemudian dilanjutkan dengan menentukan solusi yang akan ditawarkan berdasarkan diskusi tim PKM dan kondisi empiris mitra. Solusi yang ditawarkan Tim PKM adalah Pemenuhan Kebutuhan Pokok Mahasiswa UNESA Terdampak Covid-19. Kemudian dilanjutkan dengan pelaksanaan kegiatan PKM yakni Penyaluran Bahan Pokok. Setelah kegiatan dilaksanakan, tim melakukan monitoring dan evaluasi terkait pelaksanaan kegiatan PKM. Tahapan akhir adalah menyusun laporan atas kegiatan yang telah dilaksanakan.

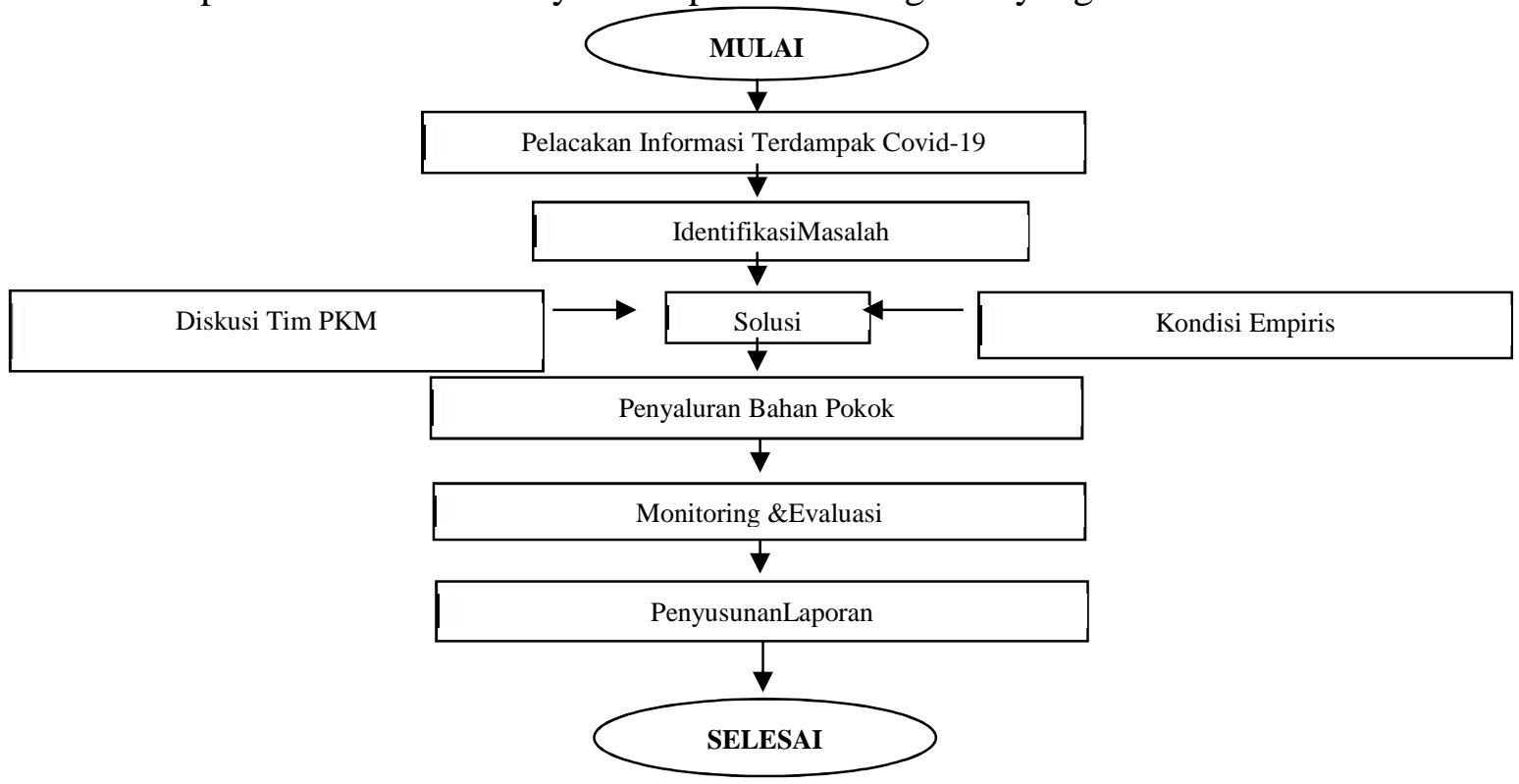

Gambar 2. Metode Pelaksanaan Kegiatan

\section{Hasil Pengabdian dan Pembahasan}

Sebagai civitas akademika Fakultas Ekonomi, Tim PKM berusaha mendukung kegiatan pemerintah untuk menunjang perekonomian masyarakat. Selama ini yang menjadi fokus target kebijakan pembangunan pemerintah adalah meningkatkan kesejahteraan masyarakat. Salah satu indikator kesejahteraan masyarakat adalah Indeks Pembangunan Manusia. Indeks Pembangunan Manusia diukur melalui pendidikan, kesehatan dan 
kemampuan daya beli masyarakat. Penelitian terdahulu menyebutkan adanya pengaruh signifikan antara kemiskinan dan pertumbuhan ekonomi terhadap Indeks pembangunan manusia (Dewi: 2017). Indeks pembangunan manusia menggambarkan seberapa baik standar hidup masyarakat (Dewi: 2014).

Standar hidup masyarakat yang baik bergantung pada besarnya kuantitas dan baiknya kualitas konsumsi mereka. Masa pandemi corona juga memberi dampak pada mahasiswa UNESA Menempuh studi mahasiswa memerlukan asupan gizi yang cukup. Jika pekerjaan orang tua mereka terdampak oleh adanya pandemi Covid-19, maka mahasiswa tidak mendapatkan pemenuhan gizi yang cukup. Kondisi tersebut tentu saja berakibat pada prestasi akademik mereka.

Tim PKM bekerjasama dengan organisasi kemahasiswaan Jurusan Ilmu Ekonomi yakni HIMA JIE. Pelibatan mahasiswa dalam kegiatan PKM akan memberikan rasa kepekaan mereka terhadap apa yang sedang terjadi di lingkungan mereka. Mahasiswa sebagai generasi penerus, perlu memiliki jiwa kemanusiaan dan kebersamaan, sehingga ketika tiba waktu mereka untuk terjun ke masyarakat mereka telah mempunyai kemampuan memahami kebutuhan masyarakat. Kemampuan ini dibutuhkan bagi mereka yang nantinya menjadi pemimpin yang memiliki tanggung jawab untuk pengambilan suatu keputusan ataupun kebijakan, baik di lingkungan sosial masyarakat ataupun lingkungan kerja.

Sebagai calon lulusan di bidang Ekonomi, mahasiswa perlu memahami dan dapat menerapkan bagaimana upaya meningkatkan kesejahteraan masyarakat. Selain dibekali pengetahuan di bidang ekonomi, mereka perlu menerapkan secara langsung bagaimana upaya meningkatkan kesejahteraan masyarakat.

Kegiatan dilaksanakan pada tanggal 14 Oktober 2020, di Fakultas Ekonomi. Teknis pelaksanaan pendistribusian kebutuhan pokok, yakni: 1) Tim PKM dan Tim Mahasiswa HIMA JIE menyiapkan paket kebutuhan pokok; 2) Tim mahasiswa HIMA JIE mengumpulkan data-data terkait mahasiswa calon penerima paket kebutuhan pokok. Tim mahasiswa HIMA JIE lebih mengetahui kondisi teman-teman mereka, sehingga penyaluran paket kebutuhan pokok lebih tepat sasaran dan dapat bermanfaat bagi mahasiswa penerima; 3) Tim mahasiswa HIMA JIE menginformasikan kepada calon penerima paket kebutuhan pokok untuk mengambil paket di Fakultas Ekonomi dengan waktu yang telah ditentukan. Fakultas Ekonomi menjadi tempat pendistribusian mengingat kondisi pandemi Corona tidak memungkinkan Tim PKM dan Tim Mahasiswa HIMA JIE untuk mendistribusikan langsung ke masing-masing rumah mahasiswa penerima paket kebutuhan pokok; 4) Mahasiswa penerima paket kebutuhan pokok, datang ke Fakultas Ekonomi untuk menerima paket, tentu saja dengan hati-hati menerapkan protokol kesehatan. Mahasiswa penerima paket kebutuhan pokok sejumlah 50 mahasiswa.

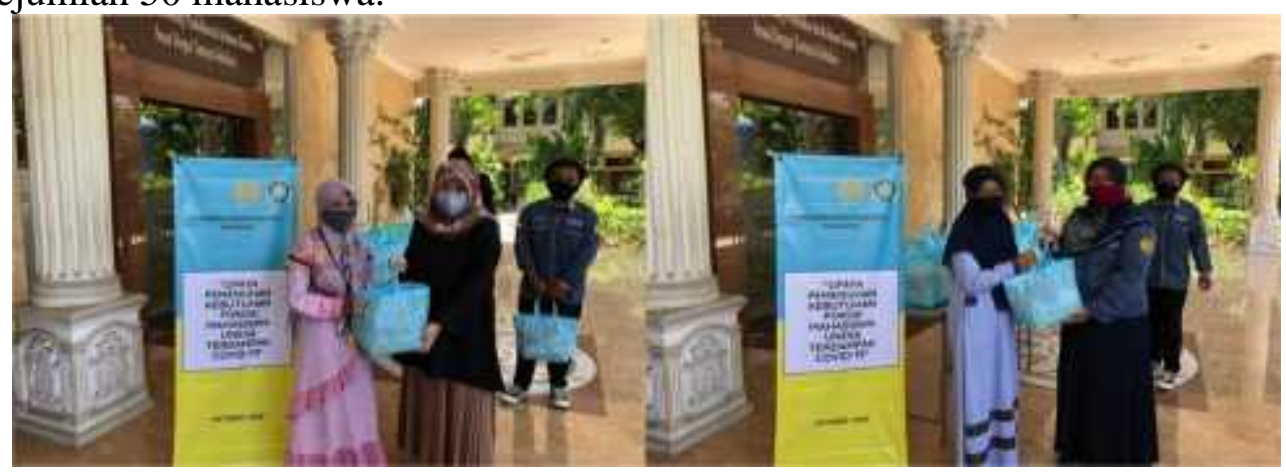




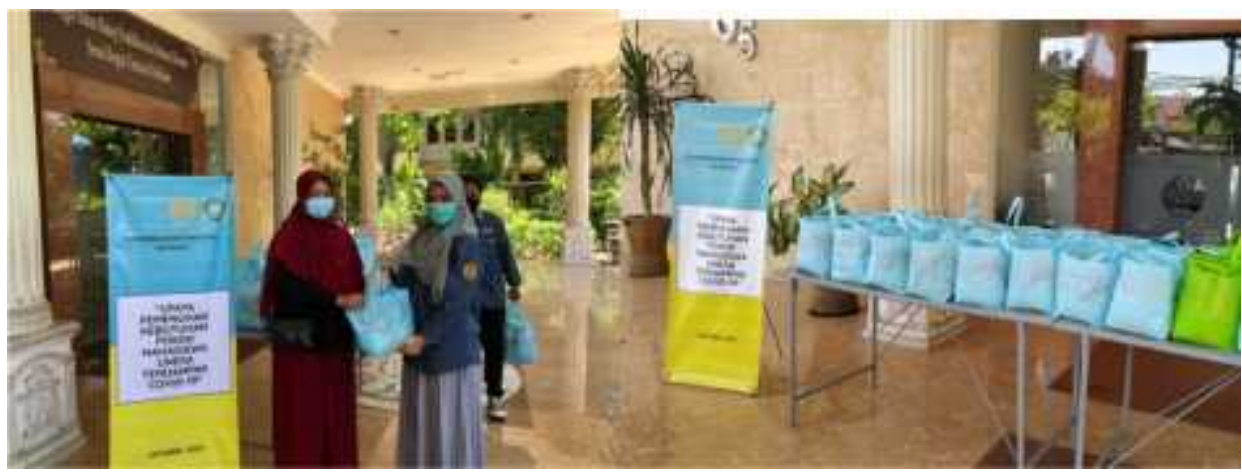

Gambar 3 Kegiatan Pendistribusian Kebutuhan Pokok

Hasil dari kegiatan ini adalah Pemenuhan Kebutuhan Pokok Mahasiswa UNESA Terdampak Covid-19 dan upaya untuk menunjang program pemerintah dalam upaya meningkatkan Indeks Pembangunan Manusia. Peningkatan Indeks Pembangunan Manusia dicapai melalui perbaikan konsumsi Mahasiswa terdampak Covid-19. Perbaikan konsumsi berhubungan dengan kemampuan daya beli masyarakat yang merupakan indikator Indeks Pembangunan Manusia. Pandemi Covid-19 memberi dampak kepada mahasiswa dengan menurunnya pendapatan kepala keluarga yang mendukung kesejahteraan keluarga, sehingga kemampuan daya beli mereka menurun. Penyaluran kebutuhan pokok membantu mereka menunjang konsumsinya, yang artinya meningkatkan standar hidup. Selanjutnya kegiatan yang direncanakan untuk dilaksanakan berikutnya, adalah melakukan suatu pelatihan softskill bagi mahasiswa terkait bisnis online, sehingga mahasiswa mampu secara mandiri memperoleh pendapatan dan membantu keluarga disamping mereka kuliah.

\section{Kesimpulan}

Kesimpulan yang diperoleh dari hasil kegiatan pengabdian ini adalah Pemenuhan Kebutuhan Pokok Mahasiswa UNESA Terdampak Covid-19 dan kegiatan ini sebagai upaya untuk menunjang program pemerintah dalam upaya meningkatkan Indeks Pembangunan Manusia.

\section{Saran}

Saran dari kegiatan pengabdian ini adalah agar kegiatan selanjutnya dapat melakukan suatu pelatihan softskill bagi mahasiswa terkait bisnis online, sehingga mahasiswa mampu secara mandiri memperoleh pendapatan dan membantu keluarga disamping mereka kuliah. Tidak hanya terkait dengan pemenuhan kebutuhan pokok saja, namun lebih pada upaya peningkatan motivasi berusaha mandiri.

\section{Daftar Pustaka}

Aji TN., dkk. (2020). Peran Zakat, Infaq dan shadaqah dalam Mengurangi Beban Ekonomi Masyarakat Terdampak COVID 19. Inspirasi: Jurnal Pengabdian dan Pemberdayaan Masyarakat Volume 1 Nomor 1, February 2021. Doi: https://journal.inspirasi.or.id/jppm/article/view/29

Dewi Novita. (2017). Pengaruh Kemiskinan dan Pertumbuhan Ekonomi Terhadap Index Pembangunan Manusia Di Provinsi Riau. JOM Fekon, Vol.4 No.1 (Februari) 2017. Doi: $\quad$ https://www.neliti.com/publications/183766/pengaruh-kemiskinan-danpertumbuhan-ekonomi-terhadap-indeks-pembangunan-manusia

Dewi., N., L., S \& Sutrisna., I., K. (2014). Pengaruh Komponen Indeks Pembangunan Manusia Terhadap Pertumbuhan Ekonomi Provinsi Bali. E-JURNAL EKONOMI 
PEMBANGUNAN UNIVERSITAS UDAYANA Vol. 3, No. 3, Maret 2014. Doi: https://www.neliti.com/publications/44443/pengaruh-komponen-indeks-pembangunanmanusia-terhadap-pertumbuhan-ekonomi-provin.

Perkembangan Kasus Terkonfirmasi Positif COVID-19 di Surabaya. Diakses pada 27 Mei 2020. https://lawancovid-19.surabaya.go.id/

Riyanta, A., Nurcahyo, H., \& Santoso, J. (2020). Implementasi Paket Bantuan Sosial Sebagai Upaya Menghadapi Pandemi Covid-19. Jurnal Pengabdian UNDIKMA, 1(2), 82-86. doi:https://doi.org/10.33394/jpu.v1i2.2717

Risfianty, D., \& Indrawati, I. (2020). Pemberdayaan Kesehatan Masyarakat Melalui Pengadaan Fasilitas Cuci Tangan pada Masa Pandemi Covid-19 di Masjid dan Mushala Dusun Montong Are Tengah. Jurnal Pengabdian UNDIKMA, 1(2), 94-99. doi:https://doi.org/10.33394/jpu.v1i2.2724

Yamali, FR., \& Putri RN. (2020). Dampak Covid 19 Terhadap Perekonomian Indonesia. Ekonomis: Journal of Economics and Business, 4(2), September 2020, 384-388. Doi: http://ekonomis.unbari.ac.id/index.php/ojsekonomis/article/view/179/139 